\title{
SERBIAN-BULGARIAN HOMONYMY AND (QUASI) ENANTIOSEMY IN BULGARIAN LANGUAGE TEACHING
}

Овај рад представља наставак нашег научноистраживачког пројекта, који се бави одступањима (на фонолошком, морфолошком и лексичком нивоу) од књижевне норме у настави бугарског језика у школама на територији Источне Србије. Овом приликом аутор усредсређује пажњу на лексичке грешке и омашке настале услед деловања међујезичке српско-бугарске (бугарско-српске) хомонимије и (квази)енантиосемије и нуди примену адекватних употребљивих решења за њихово свођење на минимум у настави.

Кључне речи: међујезичка хомонимија, међујезичка енантиосемија, међујезичка квазиенантиосемија, хомонимни лексички пар, енантиосемични лексички пар, квазиенантиосемични лексички пар.

\section{Introductory Notes}

The Bulgarian language is learned in primary and secondary schools in the territory of Eastern Serbia (in the municipalities of Dimitrovgrad and Bosilegrad), where the largest concentration of the Bulgarian ethnic diaspora lives. The standards and the models of its adoption in the said schools are regulated by the following laws: the Law on Fundamentals of the Education System, Law on Primary Education, Law on Secondary Education, etc.. The target group of our research consisted of pupils and the Bulgarian language teachers in the primary school in Dimitrovgrad.

The research focuses on the problems in teaching Bulgarian as a mother tongue making reference to the influence of the Serbian - Bulgarian lexical homonymy and enantiosemy in one-way and two-way communication (verbal and written forms of communication) due to local dialect and the Serbian and Bulgarian literature.

The purpose of the paper is twofold - to discover the factors that have an impact on the appearance and effects of this semantic phenom- 
enon, and to offer solutions on how to make limits or reduce it to a minimum in schools and in out-of-school communication.

Serbian and Bulgarian are neighbouring and close neighbourhood languages with an identical genetic (the South Slavic) basis, and many common features are apparent on various structural levels (phonetic, grammatical and lexical). Overlapping of cultures and historical development have resulted in a formally similar or identical lexeme layer. A major part of this lexical layer is also semantically identical, which makes a good basis for smooth communication. However, the other part of the layer is the lexeme corpus with various, sometimes even opposite semantic content which often results in semantic confusion, the impossibility to decode the message, frequently with funny effects in communication, but also appearing in undesirable situations. This is supported by two examples of wrong choice of semantic analogues from the verbal and written activities of pupils in elementary schools, where Bulgarian is learned as the national minority language. A $6^{\text {th }}$ grade pupil answered the question why his school mate was absent as follows: В болницайа е, ойсиираниха му gватиа крайника (У болници је, одстранили су му оба уда $\leftarrow$ Не is in hospital, he had his both limbs removed.). So, he gave information according to which his schoolmate had no more extremities (arms or legs) after surgery, which was incorrect. In this case, the pupil has made a semantic mistake by equating two formally similar lexemes - the Serbian lexeme крајник (Bulgarian сливица, English - tonsils $\longleftarrow$ and the Bulgarian lexeme крайник (Serbian уд, English $\operatorname{limb}$ ). This mistake in translation resulted from inter-lexical homonymy, which in our previous research was defined as an (optional) semantic change in realization of the lexical pair members of the same rank in communication. The following two examples illustrate the wrong choice of analogues of opposite semantic contents on an interlinguistic level. The first example implies incorrect semantic equalization of the lexeme from the enantiosemic pair вреgеши $и$ (Bulgaria струвам, English valuable) // вредя (Serbian штетити, шкодити, English harm-

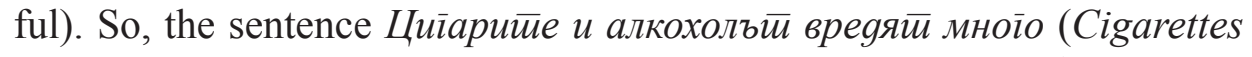
and alcohol are very harmful) in the written translation of a $5^{\text {th }}$ grade pupil the sentence reads: Циіарейе $и$ алкохол вреgе йуно (Cigarettes and alcohol are very valuable), but the correct translation reads: Циїарейе $u$ 
алкохол су веома шииейни. (Cigarettes and alcohol are very harmful). The second example refers to a semantic equalization of a lexeme from the quasienantiosemy pair йлах (буї. буен, English irascible) $\square$ йлах (Serbian плашљив, бојажљив, English timid) in a verbal presentation by an $8^{\text {th }}$ grade pupil in Bulgarian literature class. Talking about the outlaw Shibil, the pupil describes him as follows: Аз си иреястиавям Шибил кайо буен и йлах човек, (Замишљам Шибила као бујног̄ и бојажљивоі човека (English $\leftarrow$ I imagine Shibil as a robust and timid man), which is logically and factually incorrect: the hero of the story is really robust, which means that he cannot be timid at all.

In our opinion, the factors that influence the occurrence of interlanguage homonymy and (quasi)enantiosemy in teaching the Bulgarian language and literature are the following:

1) the local dialect influence. The Bulgarian scientist, Cenka Ivanova points out this factor in her research, stating that “... in its quality of a mother tongue the local dialect of the Bulgarian language is essential in everyday communication, interpersonal contacts in populated places and work collectives where more than $90 \%$ of the population is Bulgarian. The use of the Bulgarian language (written and spoken) is restricted to the primary and secondary schools, in the cultural and public life on the account of the use of the local dialect...".

2) the Serbian language norm influence. Ivanova writes: "The Bulgarian-Serbian diglossia (a term that applies to a contact of close systems with some matching components and functionally-stylistic hierarchy) is typical of middle-aged and younger generations. We would also add the fact, which is a finding of our research, that every fifth Serbian and Bulgarian lexeme is homonymic or (quasi) enantiosemic on the inter-language level, therefore it is much easier to use it semantically incorrectly in verbal or written communication.

3) lack of comparative elements with the Serbian literary language, with a focus on both languages interference in textbooks and workbooks. The fact is also stressed by the authors of the research, devoted to the state and trends in development of the teaching process in primary and secondary schools in Dimitrovgrad. 
As far as we know the essence of homonymy in the Bulgarian language is taught in the eighth grade (in the workbook, page 50), whereas the inter-language homonymy has not been included even in the most recent textbooks, which we considered to be a failing.

4) existence of insufficiently balanced bilingualism in pupils (and generally in the Slavic bilinguals), who, according to E. Houten use "less than two but more than one language norm". Since they suppose that they have mastered both language codes, the mistakes resulting from inter-language homonymy are often made because the corresponding equivalent is the first word taken from the spectrum of associations which in their mother tongue is caused by a lexeme from another language.

5) state of compression. It occurs in pupils due to their nervousness and lack of time to choose the semantic analogue when translating from one language to another.

The above mentioned factors could have an individual effect, or combined influence depending on the linguistic competence of the participants (pupils) in the communication. It is very difficult to suppose or predict when and which factors may cause inter-language homonymy or enantiosemy.

Measures for elimination of inter-language homonymy and (quasy) enantiosemy:

1) Reaching the maximum level of linguistic competence of the Bulgarian language teachers by creating an educational network. It would include various forms of qualification directed to bilingual education, intercultural communication, etc.

2) Elimination of inter-language homonymy and (quasy)enantiosemy. In our opinion, the Bulgarian language teacher should pay attention to this problem in the initial phase of the teaching process through adequate exercises (verbal or written), which have to correspond to the pupils' age. Therefore, it implies that future textbooks and workbooks should include games and exercises for the elimination of the interference problem. We generally propose that the problem should be treated through games in textbooks or in workbooks. For example, below the picture of a hive with bees and a basket, the pupils should write the corresponding word in Serbian and in Bulgarian. By doing so, they would immediately no- 
tice that Serbian кошница (English hive) and Bulgarian кошница (Serbian корйa, English basket) do not match semantically. In the next phase of the educational process (V-VIII grades) appropriate exercises could apply. For example, the pupils are given a text for translation from Serbian into English (or vice versa), where they have to discover lexemes that are homonymic or (quasy)enantiosemic on the inter-language level, then they could be invited to make sentences with lexemes that are members of a homonymic or (quasy)enantiosemic pair, etc. such as the homonymic pair буква (Bulgarian бук, English beеch) / буква (Serbian слово, English letter), enantiosemic pair коренак (Bulgarian коренче, English root) // коренак (Serbian корење, English roots) and (quasy)enantiosemic pair вреgан (Bulgarian работлив, English diligent) вреgен (Serbian. штетан, English harmful).

3) Making appropriate lexicographical instructions for school children. Two lexical homonymy dictionaries have been published so far Serbian-Bulgarian and Bulgarian-Serbian. The first one is a part of the Serbian-Bulgarian thematic and homonymy dictionary. The second one - Бълірарско-сръбски речник на лексикалниие омоними - has been significantly expanded and amended as compared to the previous dictionary of homonyms.

\section{Conclusion}

Overcoming the semantic problems related to the influence of the Serbian and Bulgarian homonymy and (quasi) enantiosemy after implementing and taking the aforesaid measures would significantly contribute to pupils' maximally balanced bilingualism. This would greatly facilitate linguistic transfer from one language to another, whereby the influence of the local dialect would be eliminated or reduced to a minimum in verbal and written expression and communication.

\section{References:}

Алексић 1996: Мариана Алексић, Наблюgения върху бълїаросръбскайа енаниииосемия, Българистични проучвания, бр. 1, 161- 
168, Международен семинар по български език и култура, Велико Търново.

Алексич М., Георгиева Д., Смилкович С., Стоянович С. 2003: Мариана Алексич, Дешка Георгиева, Стана Смилкович, Славка Стоянович Рабойна йейраяка йо бълїарски език и литерайура за 8. клас на основните училищз, Београд.

Алексић 2006물 Мариана Алексић, Међујезичка срӣско-буіарска (буїарско-срӣска) лексичка хомонимија, Београд: Филолошки факултет.

Алексић 2006²: Мариана Алексић, Бъліарско-сръбски речник на лексикалните омоними, Београд: Завод за уџбенике и наставна средства.

Алексић 2010: Мариана Алексић, Међујезичка именичка енаниииосемија (на майеријалу срӣско-буіарских хомонимских йарова), Научни састанак слависта у Вукове дане, књ. 39/1, Београд, 257-263.

Зарков А., Трифонов Пл. 2004: Антон Зарков, Пламен Трифонов, Сръбско-бълїарски речник, София.

Иванова 2004: Ценка Иванова, Близки и различни. Южнославянски езикови йроекции. В. Търново: УИ „Св. св. Кирил и Методий““

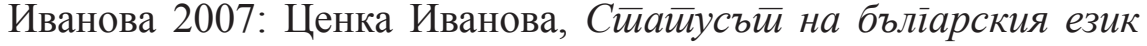

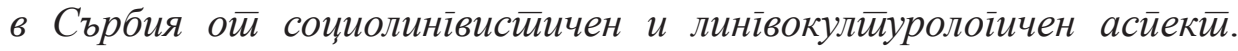
В: Бълїарскийе оситрови на Балканииее. Научна конференция в СУ „Българските „острови“ на лингвистичната карта на Балканите“.

Иванова, Алексич 2007: Ценка Иванова, Мариана Алексић, Сръбско-бълїарски речник - Темайичен. Омонимен, Завод за уџбенике, Београд.

Младенов 2000: Марин Младенов, Буїарско-срӣски речник, Завод за уџбенике и наставна средства, Београд.

Радкова А., Петров А., Падешка М., Давитков И. 2014: Антония Радкова, Ангел Петров, Мая Падешка, Ивана Давитков, Обучениейо йо бълїарски език в ірр. Димийровіраg, рейублика Сърбия-реалносиии и иееняенции Bulgarian Language and Literature, Volume 56, Number 2, 2014 , Бълїарски език и лийерайура София бр. 14, 2014.

Стефанова Л.,МанчевЙ. 1978: Лидия Стефанова,Йордан Манчев,

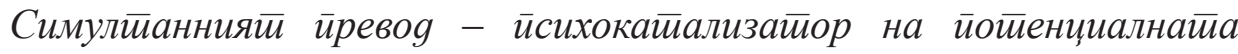
иниеерференщия межgу рояния и чужя език, бр. 6, София, стр. 63, Издание на Софийския университет „Климент Охридски”. 
Хаутен 1972: Э. Хаутен, Языковый контйакй, Новое в лингвистике, Москва 1972.

\author{
Abbreviations: \\ буг. - Bulgarian \\ енгл. - English \\ cp. - Serbian \\ Symbols: \\ $=$ semantic equivalence \\ $\neq$ semantic non-equivalence \\ / homonymic relation between formally similar lexemes \\ // enantiosemic lexemes \\ quasienantiosemic relation between formally similar lexemes
}

\begin{abstract}
The research draws attention to one of the problems in Bulgarian language teaching in primary and secondary schools of Eastern Serbia, which is the presence and influence of Serbian-Bulgarian (Bulgarian- Serbian) homonymy and enantiosemy in the process of adopting and using the Bulgarian lexical system. The author points out the factors that influence the state of being a homonym and proposes mechanisms for its reduction to minimum in communication (written and verbal).

Keywords: inter-language homonymy, inter-language enantiosemy, inter-language quasienantiosemy, homonym lexical pair, enantiosemy lexical pair, quasienantiosemy lexical pair
\end{abstract}

\title{
Biographical statement
}

DR MARIANA ALEKSIĆ was born in 1953 in Varna, Bulgaria. She graduated from the Faculty of Philology, study group for the Bulgarian language and literature in Shumen, and postgraduate and doctoral studies at the Faculty of Philology in Belgrade. Dr. Aleksić is an author of two monographs: Interlingual Serbian-Bulgarian (Bulgarian-Serbian) lexical 
homonymy (2006) and Serbian-Bulgarian (Bulgarian-Serbian) enantiosemy and quasi-enantiosemy (2015), both published by the Faculty of Philology in Belgrade. She has authored over a dozen papers dealing with Serbian-Bulgarian lexical semantic relations, as well as a number of articles related to the issues of the reception of translations from Serbian into Bulgarian. M. Aleksić is the author of over ten textbooks designed for the teaching of Bulgarian as the first language for the children of the Bulgarian ethnic minority in Serbia. Fields of scientific interest: comparative lexicology and lexicography, theory of translation and the methodology of teaching Bulgarian in a foreign environment.

E-mail: mariana.bane@gmail.com 